\title{
Emerging genetic complexity and rare genetic variants in neurodegenerative brain diseases
}

\author{
Federica Perrone ${ }^{1,2}$, Rita Cacace ${ }^{1,2}$, Julie van der Zee ${ }^{1,2}$ and Christine Van Broeckhoven ${ }^{1,2^{*}}$ (D)
}

\begin{abstract}
Knowledge of the molecular etiology of neurodegenerative brain diseases (NBD) has substantially increased over the past three decades. Early genetic studies of NBD families identified rare and highly penetrant deleterious mutations in causal genes that segregate with disease. Large genome-wide association studies uncovered common genetic variants that influenced disease risk. Major developments in next-generation sequencing (NGS) technologies accelerated gene discoveries at an unprecedented rate and revealed novel pathways underlying NBD pathogenesis. NGS technology exposed large numbers of rare genetic variants of uncertain significance (VUS) in coding regions, highlighting the genetic complexity of NBD. Since experimental studies of these coding rare VUS are largely lacking, the potential contributions of VUS to NBD etiology remain unknown. In this review, we summarize novel findings in NBD genetic etiology driven by NGS and the impact of rare VUS on NBD etiology. We consider different mechanisms by which rare VUS can act and influence NBD pathophysiology and discuss why a better understanding of rare VUS is instrumental for deriving novel insights into the molecular complexity and heterogeneity of NBD. New knowledge might open avenues for effective personalized therapies.
\end{abstract}

Keywords: Neurodegenerative brain diseases, Alzheimer's disease, Parkinson's disease, Frontotemporal dementia, Amyotrophic lateral sclerosis, Rare coding variants, Missense mutations, Frameshift mutations, Gene discovery, genetic variants of uncertain significance (VUS), functional research

\section{Background}

Neurodegenerative brain diseases (NBD) are progressive and irreversible fatal conditions primarily affecting the neurons of the central nervous system (CNS). At the cellular level, NBD are characterized by cytoplasmic or nuclear protein aggregations [1]. Dementia symptoms are typical features of NBD and imply a great burden for patients and caregivers [2]. The most frequent NBD subtypes are Alzheimer's disease (AD) and Parkinson's disease $(\mathrm{PD})$, followed by the less frequent frontotemporal

\footnotetext{
* Correspondence: christine.vanbroeckhoven@uantwerpen.vib.be ${ }^{1}$ Neurodegenerative Brain Diseases Group, VIB Center for Molecular Neurology, Antwerp, Belgium

${ }^{2}$ Department of Biomedical Sciences, University of Antwerp - CDE, Universiteitsplein 1, BE-2610 Antwerp, Belgium
}

dementia (FTD) and amyotrophic lateral sclerosis (ALS). The disease characteristics of the NBD subtypes are summarized in Table 1.

In the last three decades, linkage studies in extended NBD families with a Mendelian inheritance of NBD identified high-penetrant mutations in causal genes and co-segregation with NBD [3, 4]. Causal genes, routinely tested in medical genetic centers for AD, PD, FTD, and ALS, are listed together with mutation spectrum and inheritance patterin in Table 2.

International genome-wide association studies (GWAS) in large cohorts of NBD patients or healthy individuals identified common variants in novel genes showing significant associations to NBD, but with a modest increase in disease risk [20-23]. GWAS NBD

(c) The Author(s). 2021 Open Access This article is licensed under a Creative Commons Attribution 4.0 International License, which permits use, sharing, adaptation, distribution and reproduction in any medium or format, as long as you give appropriate credit to the original author(s) and the source, provide a link to the Creative Commons licence, and indicate if changes were made. The images or other third party material in this article are included in the article's Creative Commons licence, unless indicated otherwise in a credit line to the material. If material is not included in the article's Creative Commons licence and your intended use is not permitted by statutory regulation or exceeds the permitted use, you will need to obtain permission directly from the copyright holder. To view a copy of this licence, visit http://creativecommons.org/licenses/by/4.0/. The Creative Commons Public Domain Dedication waiver (http://creativecommons.org/publicdomain/zero/1.0/) applies to the data made available in this article, unless otherwise stated in a credit line to the data. 
Table 1 Main characteristics of NBD subtypes

\begin{tabular}{llll}
\hline NBD & Brain location & Pathology & Main symptoms \\
\hline AD & Tempo-parietal lobes & B-Amyloid, tau & Progressive memory loss, cognitive decline \\
FTD & Frontotemporal lobe & TDP43, tau, FUS & Behavioral changes, language deficits \\
PD & Midbrain & a-Synuclein, Lewy bodies & Bradykinesia, muscle rigidity, resting tremor. Dementia features in 30-80\% \\
ALS & Motor cortex, spinal cord & TDP-43 & Muscle weakness, impaired voluntary movements. Dementia features in 50\% \\
\hline
\end{tabular}

risk genes for $\mathrm{AD}, \mathrm{PD}, \mathrm{FTD}$, and ALS are listed in Table 3.

The genetic discoveries in NBD, i.e., AD, PD, FTD, and ALS contributed to a better understanding of the biological mechanisms underlying CNS neurodegeneration. But, they were not able to adequately disclose the entire genetic background of these complex NBD disorders [37], since NBD is not yet genetically explained in numerous patients [38]. NGS tools, like whole-exome (WES) or whole-genome sequencing (WGS), played a critical role in understanding the pathogenic mechanisms leading to NBD, due to the identification of various novel genes [39-41]. These studies shed a new light on the specific pathways that contribute to NBD pathophysiology. A non-exhaustive list, includes microgliamediated pathway in $\mathrm{AD}$ [20], mitochondrial dysfunction in PD [39], RNA stress response in ALS [40], and lysosomal disruption in FTD [42].

A challenge of these sequencing technologies is the identification of countless rare variants, specifically variants of uncertain significance (VUS) [43, 44]. For a long time, these rare variants were considered noncontributing genetic background without effect on the NBD disease. Consequently, these VUS were ignored, resulting in a lack of supportive genetic and functional data. The rare VUS can be classified based on their likelihood of pathogenicity by using in silico bioinformatic prediction tools [45], but these predictions are insufficient particularly in the situation of a genetic diagnosis of patients [46].

In this review, we focus on rare variant interpretation in NBD phenotypes such as AD, FTD, PD, and ALS. We describe discoveries from WES and WGS studies, including the novel pathways involved in these disorders. We suggest modes of action and strategies for the interpretation of VUS, providing examples of rare variants in established causal genes and GWAS risk genes. We address the impact of improved understanding of rare variants for patients and families and for therapy development. Finally, we deliberate on the potential of omics technologies in unraveling of the genetic etiology and molecular pathways leading to neurodegeneration.

\section{WES and WGS reveal novel genes and pathways}

WES and WGS are mainly used in NBD genetic research to uncover novel genes and pathways [47]. Hand in hand, specific statistical approaches are developed for

Table 2 Causal genes, mutation spectrum, and mode of inheritance

\begin{tabular}{|c|c|c|c|c|}
\hline NBD & Causal gene & Type of mutation* & Inheritance & $\overline{\text { Reference }}$ \\
\hline \multirow[t]{4}{*}{$\overline{A D}$} & Amyloid precursor protein (APP) & Missense, gene dosage & Autosomal dominant, recessive & [5] \\
\hline & Presenilin 1 (PSEN1) & Missense, indels & Autosomal dominant & [3] \\
\hline & Presenilin 2 (PSEN2) & Missense, indels & $\begin{array}{l}\text { Autosomal dominant } \\
\text { de novo }\end{array}$ & {$[6]$} \\
\hline & Prion protein (PRNP) & Missense, indels & Dominant & {$[7]$} \\
\hline \multirow[t]{3}{*}{ PD } & a-Synuclein (SNCA) & Missense, gene dosage & Autosomal dominant & {$[4]$} \\
\hline & Parkin 2 (PARK2) & Missense, gene dosage & Autosomal recessive & {$[8]$} \\
\hline & Leucine-rich repeat kinase 2 (LRRK2) & Missense & Autosomal dominant & [9] \\
\hline \multirow[t]{2}{*}{ FTD } & Granulin (GRN) & PTC & Autosomal dominant & [10] \\
\hline & Microtubule-binding protein tau (MAPT) & Missense, gene dosage & Autosomal dominant & [11] \\
\hline \multirow[t]{3}{*}{ ALS } & Fused in sarcoma (FUS) & Missense & Autosomal dominant & [12] \\
\hline & Cu/Zn superoxide dismutase (SOD1) & Missense & Autosomal dominant & [13] \\
\hline & Transactive response DNA-binding protein (TARDBP) & Missense & Autosomal dominant & [14] \\
\hline \multirow[t]{3}{*}{ FTD and ALS } & Chromosome 9 open reading frame 72 (C9orf72) & $\mathrm{G}_{4} \mathrm{C}_{2}$ repeat expansions & Autosomal dominant & [15] \\
\hline & TANK-binding kinase 1 gene (TBK1) & PTC & Autosomal dominant & [16-18] \\
\hline & Valosin-containing protein gene (VCP) & Missense & Autosomal dominant & [19] \\
\hline
\end{tabular}

*Abbrevations: indel, insertion/deletion; PTC, premature termination codon 
Table 3 NBD risk genes identified in GWAS

\begin{tabular}{|c|c|c|}
\hline NBD & Risk genes & References \\
\hline$\overline{A D}$ & $\begin{array}{l}\text { ABCA7, ACE, ADAM10, ADAMTS1, APOE, BIN1, BCKDK, CASS4, CD2AP, CD33, CELF1, CLU, CR1, DSG2, EPHA1, FERMT2, HLA-DRB1, HLA- } \\
\text { DRB5, INPP5D, IQCK, KAT8CR1, MEF2C, MS4A6A, NME8, PICALM, PTK2B, SLC24A4, SORL1, WWOX, ZCWPW1 }\end{array}$ & [24-30] \\
\hline PD & $\begin{array}{l}\text { ACMSD, ASXL3, BCKDK, BRIP1, BST1, C5orf24, CAB39L, CCDC62, CD19, CHRNB1, CLCN3, CRLS1, DDRGK1, DGKQ, DNAH17, DYRK1A, } \\
\text { FAM171A2, FAM47E, FAM49B, FBRSL1, FCGR2A, FGF20, FYN, GAK, GBA, GBF1, GPNMB, HIP1, HLA-DQB1, HLA-DRA, HLA-DRB5, INPP5F, } \\
\text { KCNIP3, KCNS3, KPNA1, LAMP, LCORL, LINC00693, MAPT, MBNL2, MCCC1/3, MED12L, MEX3C, MIPOL1, NOD2, NUCKS, PAM, RAB29, } \\
\text { RAB7L1, RAI1, RIMS1, RIT2, RNF141, RPS12, RPS6KL1, SCAF11, SCARB2, SIPA1L2, SNCA, SPTSSB, SREBF1, STBD1, STK39,STX1B, SYT11, } \\
\text { TMEM163, TMEM175, TRIM40, UBAP2, UBTF, VAMP4, VPS13C }\end{array}$ & {$[22,31-33]$} \\
\hline FTD & BTNL2, C4orf27, CTSC, DPP6, HLA-DRA, HLA-DRB5, HLA-DQA2, IMMP2L, IRF2, MIR548AP, OLFM1, RAB38, RERG, TMEM106B, UNC13A & {$[21,34]$} \\
\hline ALS & C21orf2, DPP6, FGGY, ITPR2, KIF5A, MOBP, SARM, SCFD1, UNC13A & {$[23,35,36]$} \\
\hline
\end{tabular}

accurate data analysis and rare variant identification [47, 48]. These tests, analyzing the contribution of multiple variants across candidate gene(s), have increased the power to detect disease association signals [48], often disclosing the clustering of genes in specific pathways.

Examples of recently discovered pathways by application of NGS include microglia alterations in $\mathrm{AD}$, mitochondrial dysfunction in PD, RNA stress response in ALS, and lysosomal disruption in FTD [20, 40, 42, 49].

In $\mathrm{AD}$, besides amyloid processing [50], it is demonstrated that the microglia-mediated pathway is a crucial contributor to the pathogenesis of $\mathrm{AD}$ [20]. Rare variants in the triggering receptor expressed on myeloid cells 2 (TREM2) were discovered by WGS, showing an increased risk for developing AD [51]. TREM2 encodes a receptor expressed in myeloid cells that mediates inflammatory responses. The relevance of TREM2 in brain functioning is highlighted by recessive mutations in TREM2 causing Nasu Hakola disease, and FTD in some patients [51]. Rare heterozygous TREM2 mutations that increase the risk for developing disease have been described in AD, FTD, ALS, and PD [51], though their role in disease pathogenesis needs further follow-up. The implication of microglial-mediated inflammation in NBD is confirmed by the identification of rare variants in phospholipase $\mathrm{C}$ gamma 2 (PLCG2) in AD and ABI family member $3(A B I 3)[52]$.

A wide range of evidence indicates mitochondrial dysfunction and mitophagy as important players in PD pathology [53]. A WES study in autosomalrecessive early-onset $\mathrm{PD}$ patients identified rare homozygous or compound heterozygous PTC mutations in the vacuolar protein sorting-associated protein 13C gene (VPS13C) [54]. VPS13C belongs to a family of vacuolar sorting proteins that are crucial for vesicular transport. VPS13C depletion in neuronal cells leads to the upregulation of the PTEN-induced kinase 1 (PINK1)/parkin (PARK2) gene-dependent mitophagy, where PINK1 normally accumulates on the mitochondria and recruits parkin to initiate mitophagy in response to mitochondrial dysfunction. Moreover, VPS13C loss is associated with lower mitochondrial membrane potential, mitochondrial fragmentation, and increased respiration rates [54].

In ALS, several disease-related genes encode for RNAbinding proteins that interfere with the formation of stress granules [40]. One gene, coding for cytotoxic granule-associated RNA-binding protein (TIA1), was identified by WES in a family with both FTD and ALS patients [55]. Mutations in TIA1 were previously linked to autosomal dominant Welander distal myopathy [56], a muscular dystrophy disease characterized by TAR DNA-binding protein 43 (TDP-43) brain pathology as present in FTD and ALS. TIA1 RNA-binding protein forms stress granules in the cytoplasm upon cellular stress [40]. Rare TIA1 mutations, linked to FTD and ALS, alter the biophysical properties of TIA1 promoting nucleation of the stress granules and hindering disassembly as the stress stimulus passes [40]. Specific to FTD is that the lysosomal pathway is involved in the pathogenic events leading to disease [18]. This pathway has a role in the degradation of long-lived proteins. Deficits in this pathway result in protein aggregation and generating toxic protein species and accumulation of dysfunctional organelles [57].

Rare PTC mutations were identified by WES in the TANK-binding kinase 1 gene (TBK1) leading to the loss-of-function (LOF) of TBK1 and causing FTD or ALS [58]. TBK1 codes for a serine/threonine kinase, phosphorylating a wide range of substrates involved in several cellular processes, including autophagy. Substrates of TBK1 are optineurin (OPTN) and p62/sequestosome 1 (SQSTM1), which are autophagy adapters controlling protein degradation by selective autophagy. In both genes (OPTN and SQSTM1), rare mutations were found associated with FTD or ALS. The valosincontaining protein gene $(V C P)$ is another gene contributing to FTD and ALS genetic etiology and is also involved in autophagy, emphasizing the major role of autophagic defects in neurodegeneration [58].

Progresses in NGS technologies drastically improved our knowledge of the multiple pathways involved in NBD, including microglia, mitochondrial dysfunction, RNA stress response, and lysosomal disruption. These 
NGS-driven gene discoveries have also intensified the identification of various rare variants which have an unclear contribution to disease. Statistical association of novel genes with NBD is insufficient to establish pathogenicity. Causal genes and genes functionally associated with a specific NBD subtype are not obligatory showing a significant statistical enrichment in patients [16], as exposed by the ATPase phospholipid transporting 10B gene $(A T P 1 O B)[49]$ and the CYLD Lysine 63 deubiquitinase gene $(C Y L D)$ [59]. The application of WES or WGS and tailored statistics analyses [47] are fruitful to enhance our understanding of the NBD pathogenesis, when the majority of NBD patients remain genetically unexplained [21].

\section{Genetic, clinical, and pathological heterogeneity in NBD}

NBD are complex diseases with a high degree of heterogeneity at the level of genetics, clinical phenotypes, and brain pathology. Besides the distinguishing clinical symptoms, brain pathologies, causal genes, and pathways, NBD present with substantial clinical, genetic, and pathological overlap $[60,61]$ which may lead to misdiagnoses of the NBD subtypes and erroneous medical treatment or result in grouping of patients for clinical trials that have different underlying pathologies.

Overlapping symptoms of clinical phenotypes, for example, AD and FTD, can affect the diagnosis of the patient at the initiate stage of disease [60].

Loss of short- and long-term memory and cognitive deficits are the classical characteristics of $\mathrm{AD}$, but some $\mathrm{AD}$ patients also present with pronounced behavioral changes reminiscent of FTD [62], highlighting the heterogeneity in a single phenotype [63]. Parkinsonism can be present in both AD and FTD patients [26, 27]. The pathological hallmarks in the autopsy brains of $\mathrm{AD}$ patients are aggregated amyloid-beta $(A \beta)$ plaques and hyperphosphorylated tau tangles. Yet, among elderly people with definite $\mathrm{AD}$ pathology, up to $90 \%$ displayed TDP-43 proteinopathy [64], typical of FTD or ALS. Several genetic studies documented the overlap between NBD subtypes, and examples can be found in the wellknown disease genes. In the microtubule (MT)-binding protein tau gene $(M A P T)$, the missense mutation p.R406W segregates in families of patients with a clinical $\mathrm{AD}$ diagnosis and a brain neuropathological of tauopathy [65], while the MAPT p.A152T mutation is a risk modifier in other NBD subtypes including AD and dementia with Lewy bodies (DLB) [66]. Mutations in PARK2 in familial early-onset PD patients are also observed in sporadic early-onset AD patients [67]. In a Belgian founder pedigree, patients carry a LOF mutation in the progranulin gene $(P G R N), G R N$ IVS1+5G $>C$ and present at autopsy with TDP-43 type A pathology [68].
Yet, in this extended family, some patient carriers received a clinical diagnosis of PD or AD [68]. In light of heterogeneity in clinical diagnoses, a profound investigation of the presence of rare variants in known causal genes and newly identified genes is of paramount importance to improve differential diagnosis [69].

\section{Relevance of understanding the role of rare variants}

In diagnostic genetic testing, WGS, WES, and gene panels are common tools for the identification of mutations in known NBD genes. Identification of rare variants is moving at a faster pace than functional biological interpretation. The data generated by these NGS technologies comprise large numbers of VUS in established disease genes which can create uncertainties as to whether rare variants contribute to disease. For example, in the known $\mathrm{AD}$ genes, 68 coding rare variants were reported in the amyloid precursor protein gene (APP), 321 in the presenilin 1 gene (PSEN1), and 63 in the presenilin 2 gene (PSEN2). Yet, a significant fraction of these rare variants has not been functionally investigated: $32.35 \%$ in $A P P, 12.77 \%$ in PSEN1, and $55.55 \%$ in PSEN2; percentages were calculated from the data in the Alzforum Database, https://www.alzforum.org/mutations, a repository of published mutations in APP, PSEN1, PSEN2, MAPT, and TREM2. Knowing the contribution of rare variants to disease etiology is highly valuable for patients and their relatives, even if there are no diseasemodifying treatments for NBD [70]. In the case of a family with a pathogenic mutation, information can be provided to relatives about genetic testing. In clinical research, mutation carriers can be included in clinical trials, as in the study "Dominantly Inherited Alzheimer Network Trials Unit (DIAN-TU)" in AD [71]. For clinical trials, the knowledge of the role of rare variants in NBD will become a critical aspect to compose homogeneous patient groups for clinical trials, based on a complete genetic profile [72]. In previous studies, patients shared the same clinical diagnosis but often differed in NBD subtype biasing the trial outcomes [73]. Difficulties in clinical differential diagnosis hampered the grouping of patients for research studies [74]. Stratification of patients can be improved by in-depth knowledge of the clinical, pathological, and genetics that are contributing to the NBD of the patient. Variant interpretation is critical for new therapeutic developments. Large families with a high variability in onset age, asymptomatic carriers of pathogenic mutations, and healthy control individuals with control-specific rare variants can be extremely valuable for uncovering possible modifying cellular mechanisms of neurodegeneration.

Induced pluripotent stem cells (iPSCs) can be generated from symptomatic and asymptomatic carriers of a 
specific variant and differentiated into specific cell types (e.g., neurons) to investigate the effect of the mutations [75]. Alternatively, genome editing technologies (e.g., CRISPR/Cas) can be applied to introduce specific mutations in iPSCs or to generate isogenic control lines [76]. Experiments on iPSCs expressing different pathogenic mutations in the PD gene, leucine-rich repeat kinase 2 (LRRK2), e.g., p.G2019S, showed disrupted mechanisms including aggregation of $\alpha$-synuclein, mitochondrial transport, and lysosomal autophagy [77]. These iPSCs are also beneficial to measure the resulting cellular phenotypes to allow the identification of new therapeutics [78]. For instance, a library including 1258 pharmaceutical compounds was applied to iPSC-derived AD neurons, measuring the secretion of $A \beta$ species (e.g., toxic $\mathrm{A}(342)$, as an output. In this way, it was possible to identify potential therapeutic compounds able to reduce A $\beta 42$ levels [78].

Three-dimensional (3D) brain organoids derived from human PSCs (hPSCs) and iPSCs can recapitulate the brain's 3D cytoarchitectural arrangements and provide new opportunities to explore disease pathogenesis [79]. In a recent study, the classical $\mathrm{AD}$ phenotypes were recapitulated in familial $\mathrm{AD}$ patient-derived 3D brain organoids obtained from familial early-onset $\mathrm{AD}$ patients carrying an APP duplication [80]. The application of these methodologies can be extended to VUS to verify their possible implication in pathogenic mechanisms underlying an NBD phenotype. In addition, supplementary omics tools are being developed and will provide new opportunities to enhance our understanding of disease mechanisms and investigate how rare variants contribute to NBD pathogenesis.

\section{Possible modes of action of rare variants in known genes: the penetrance spectrum}

We speculate that rare variants can use different modes of action to contribute to NBD and report some key examples of rare variants in known causal and risk genes that recapitulate these modes of action. In-depth NGS re-sequencing of known causal and GWAS risk genes in large study populations led to the detection of huge numbers of rare variants. There is increasing evidence that rare variants of high to intermediate penetrance, and common risk variants with minor effect, are contributing to NBD genetic complexity via different modes of action (Fig. 1).

Haploinsufficiency caused by LOF due to a PTC mutation resulting from a frameshift, nonsense, or splice site mutation is the pathogenic mechanism associated with GRN in FTD and with TBK1 in ALS, FTD, and ALS plus FTD. In addition to PTC mutations, genetic studies reported rare missense variants in both GRN and TBK1, but their contribution to disease is not yet clear due to limited functional data. In cerebrospinal fluid (CSF) and plasma or serum of GRN PTC carriers, GRN levels are reduced to $50 \%$, in line with haploinsufficiency of pathogenic GRN PTC mutations [81]. Additionally, few GRN

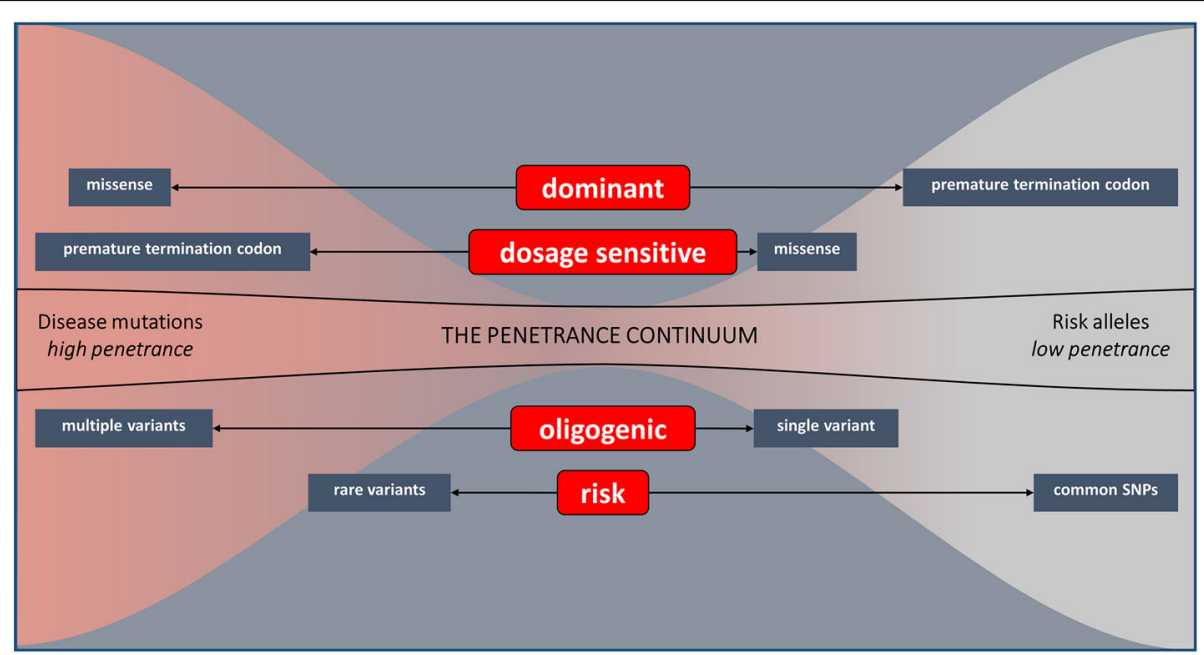

Fig. 1 The figure illustrates the penetrance continuum of disease mutations at the extremes, high penetrance (left) and low penetrance (right). The missense mutations in autosomal dominant disease genes (e.g., PSEN1) are highly pathogenic (extreme left) while the role of rare PTC variants needs to be addressed (extreme right). In dosage-sensitive genes (e.g., GRN), PTC mutations are highly pathogenic (extreme left), but rare missense mutations have variable effects on protein function (right). Oligogenic inheritance might explain the reduced penetrance of some pathogenic mutations, in both dominant and dosage-sensitive genes, since one single variant is not penetrant enough to cause the disease on itself. Combinations of multiple rare variants in disease genes increase the effect on gene expression and disease penetrance (extreme left). In risk genes (e.g., ABCA7), common rare single-nucleotide polymorphisms (SNPs) result in a modest increase of disease risk (extreme right), while rare variants can be highly pathogenic and resemble autosomal dominant inheritance in families (left) 
missense variants also reduced GRN to intermediate levels in GRN PTC carriers and control individuals [81]. The observation of GRN missense variants highlights their possible involvement in disease pathogenesis. Further, in vitro studies showed that the GRN p.P248L and p.R432C variants affect GRN secretion and degradation $[82,83]$. A direct link between disease and biological mechanisms triggered by missense variants is yet to be demonstrated. Deciphering the role of GRN in FTD pathogenesis can reveal additional insight into the potential pathogenicity of GRN missense mutations. Similarly, rare missense mutations in TBK1 are identified in both FTD, FTD plus ALS, and ALS patients and healthy controls $[84,85]$. In vitro studies demonstrated that specific TBK1 missense mutations affect TBK1 homodimerization, which is essential for TBK1 activation and function, for its kinase activity and its interaction with OPTN [85, 86]. GRN and TBK1 missense mutations were also observed in early-onset [87] and late-onset AD [88] patients, but they were not functionally investigated in vitro or in vivo in relation to $\mathrm{AD}$. These missense variants are important to investigate because they may impair the normal protein function to some extent. Some missense mutations are present only in healthy controls [89] and are a powerful tool to investigate protective biological processes that might slow disease progression and in developing new therapeutic strategies.

Rare PTC variants are also present in other NBD genes, but the majority are not characterized or incorrectly interpreted [60]. For example, in the AD gene PSEN2, four potential frameshift mutations were observed in patients $[60,90,91]$, while only one is labeled pathogenic in the Alzforum Database, nonetheless, it lacks functional investigation [90]. One frameshift mutation, p.G359Lfs $89 \%$, showed a nearly $50 \%$ reduction of PSEN2 protein [60]. The same study reported two PSEN2 frameshift mutations, one in an ALS and one in a FTD patient, two different clinical NBD phenotypes, suggesting that the frameshift variants are unlikely pathogenic. LOF mechanism is proposed for PSEN1 and PSEN2 mutations in AD, showing that total PSEN1 and PSEN2 LOF in mouse brain caused progressive cognitive decline and neurodegeneration [92]. For instance, the PSEN1 p.L435F and p.C410Y mutations produced almost complete loss of $\gamma$-secretase-dependent processing of APP, without A $\beta$ generation [92]. Newer evidence opposed the hypothesis of LOF for PSEN1 and PSEN2 mutations [93]. It is shown that familial PSEN1 mutations affect the endoproteolytic activities of $\gamma$-secretase in a variable way, though no examples of full inactivation have been reported [93]. Patients carrying a familial PSEN1 mutation express one normal allele of PSEN1 and two normal alleles of PSEN2 and can compensate for the loss of normal activity of the mutated allele [93].
PSEN1 and PSEN2 are the catalytic subunits of the $\gamma$ secretase complex, mainly involved in APP cleavage. Other functions are proposed, for example, PSEN2 selectively cleaves late endosomal/lysosomal localized substrates [94]. The contribution of PTC mutations in dominant genes warrants further investigation since they might interfere with secondary functions of the encoded proteins.

\section{Variable expression: age-related reduced penetrance and genetic modifiers}

To ensure accurate NBD genetic diagnoses, identification of pathogenic mutations causing disease is of major importance, but a few features may complicate their interpretation. Carriers of the same pathogenic mutation often show a wide range of variation in disease onset age and in clinical phenotype [68]. Some pathogenic mutations are also present in asymptomatic carriers aged above the average onset age in the family and in healthy participants. These observations are challenging our interpretation of rare variants and their role in disease, pointing at how crucial it is to decipher their pathological effects. For example, the APP p.A713T mutation is identified in 24 carriers, including asymptomatic carriers, of 11 Italian families who present with highly variable onset ages ranging from 52 to 82 years [60, 95]. Variable onset ages are also observed in members of the same family and unrelated carriers of the same PSEN2 mutation, p.A85V, p.N141I (Volga German mutation), p.M239V, with a difference of onset age of $\geq 20$ years [96]. In the Volga German AD families, there is evidence that the variable onset age might be explained by the influence of apolipoprotein $\mathrm{E}(A P O E) \varepsilon 4$ alleles, a major risk factor for AD [97].

In the world's largest autosomal dominant AD pedigree of about 5000 living members, spanning five to seven generations and carrying the pathogenic PSEN1 p.E280A mutation, one carrier had no signs of cognitive impairment until the seventies, three decades after the expected onset age. This carrier had high levels of amyloid $\beta$ in the brain and was homozygous for the APOE $\varepsilon 3$ Christchurch (p.R136S) mutation [98]. These findings demonstrate how strong a genetic variant can modify disease onset also in the presence of highly penetrant pathogenic mutations, supporting the role of $A P O E$ genotypes in $\mathrm{AD}$. Genetic modifiers are proposed to be associated with onset age variability in the Belgian FTD founder pedigree, segregating the GRN IVS1+5G>C LOF mutation [68]. The transmembrane protein 106B gene (TMEM106B) genotypes are shown to explain part of onset age variability in carriers of different PTC mutations in GRN leading to LOF [99].

In PD, the p.G2019S missense mutation in LRRK2 is the most common missense mutation and one of few 
LRRK2 missense mutations considered to be pathogenic based on co-segregation with disease [100]. The LRRK2 p.G2019S carriers have an onset age range from 59 to 79 years, though some carriers remain asymptomatic till 80 or 90 years [101]. Several studies searched modifiers for $L R R K 2$ p.G20129S and identified dynamin-3 (DNM3) as a candidate, however with significant heterogeneity across studies [102].

The interpretation of pathogenic mutations is unfortunately not always straightforward. Some of the mutations show variable penetrance. The presence of genetic modifiers is a plausible explanation for the reduced penetrance of these mutations. Alternatively, the effects of these pathogenic mutations may not be sufficient to trigger disease on their own, since they may need additional rare mutations in the same or other genes [103].

Rare variants can function as genetic modifiers influencing onset age, clinical phenotype, and disease penetrance, explaining part of the frequently observed variability among unrelated patients and affected relatives in one family [68]. It is possible to identify rare variants in disease genes that are protective, for example, the Icelandic $A P P$ mutation p.A673T [89]. This APP mutation is within the codon of the pathogenic $A P P$ p.A673V mutation. In Iceland, this protective p.A673T mutation is five times more frequent in healthy people than in $\mathrm{AD}$ patients and is associated with a minimal deposition of $A \beta$ in the brain. Rare variants might influence disease onset age in a way comparable to the allelic effects of the $A P O E \& 4$ allele [104]. Carriers of one or two $A P O E \varepsilon 4$ alleles have a 3- to 15-fold higher risk of developing late-onset AD [105] and are higher in early-onset AD patients (age at onset $<65$ years) with a positive family history [106]. Studies have suggested a similar role for the sortilin-related receptor 1 gene (SORL1). Some studies reported that rare SORL1 PTC variants are associated with a fivefold increased risk for early-onset $\mathrm{AD}$, suggesting a comparable risk effect for $\mathrm{AD}$ as for carriers of one $A P O E \varepsilon 4$ allele [107]. Identifying risk alleles and modifiers and understanding the role of rare VUS can be relevant to develop effective diseasemodifying therapies. Several risk genes have known druggable properties (e.g., sialic acid-binding Ig-like lectin (CD33) in AD [108]) and a translational potential to be targeted and to modify the phenotype, not only in patients but also in individuals at risk. This can help in the selection of patients for clinical trials. For instance, in AD, polygenic risk scores can be calculated to identify individuals at high risk who may benefit from specific therapies [107].

Observations of rare variants in multiple genes belonging to the same or similar biological pathway(s) have led to the concept of oligogenic inheritance to explain the complexity of NBD [103]. For many years, WES and WGS allowed the simultaneous analysis of multiple genes and the identification of multiple variants.
In ALS patients, carrying a pathogenic repeat expansion in the chromosome 9 open reading frame 72 gene (C9orf72), the concurrence of multiple variants in several ALS-associated genes is documented [103]. This explains in part why there are asymptomatic carriers of pathogenic C9orf72 expansions in ALS families [103] and might suggest that other mutated genes may be needed to fully express the disease. In the pathogenic C9orf72 expanded repeat allele, it is not easy to determine the exact number of repeats which play a role by themselves.

Different studies have shown that in ALS patients and families, carrying two or more mutations in ALSassociated genes [103], some patients are developing the disease 10 years earlier than patients carrying a single ALS gene mutation [109]. This oligogenic concept is extendable to FTD. GRN PTC mutation carriers were described to carry an additional mutation in TAR DNAbinding protein $(T A R D B P)$ or a pathogenic C9orf72 expansion [68]. The MAPT p.A152T mutation is unique in individuals in the Basque country and was found in $71 \%$ of FTD patients carrying the pathogenic GRN c.709$1 G>A$ mutation [110]. In $A D$, the presence of more than one variant in causal genes in the same patient carrier has been observed. In a Belgian AD cohort, a patient with a pathological AD diagnosis carried both the known PSEN1 p.G183V variant and the novel PSEN1 p.P49L [111]. Another AD patient was reported carrying the VUS PSEN1 p.P355S and APP p.G625_S628del [111]. However, since the number of identified double mutation carriers in FTD and AD is limited, the role of these double mutations remains unclear. In PD, there is also evidence that multiple rare variants in causal genes could influence disease, as PD patients, with more than one mutation in PD genes, have an onset age lower than patients carrying only one pathogenic PD mutation [39]. The most frequently reported double mutations are LRRK2 p.Gly2019Ser together with homozygous PARK2 mutations [39]. A study investigated oligogenic inheritance by performing WES in 980 neuropathologically characterized human brains from AD, PD, and FTDALS patients and age-matched controls [112]. The authors identified in FTD-ALS, AD, and PD, oligogenic cases defined by the presence of more than one variant in the list of NBD genes selected for the study, with minor allele frequency below 1\% in the Exome Aggregation Consortium (ExAc) database [112]. The impact of oligogenic mutations on disease expression is currently unclear due to the limited number of oligogenic mutation carriers identified so far and the lack of large families to investigate co-segregation with disease. Deciphering the contribution of rare variants to disease is therefore essential to understand these disorders.

GWAS revealed a wealth of risk genes in NBD. In these risk genes, the variants explaining the association 
have often remained elusive. Post-GWAS studies aim to decipher the functional variants in these risk loci, but they also reveal a more complex genetic picture. In the ATP-binding cassette sub-family A member 7gene ( $A B C A 7)$, both common and rare variants are reported to affect $\mathrm{AD}$ risk [113]. Rare $A B C A 7$ PTC variants of intermediate to high penetrance are observed with a 1.5-4-fold increased frequency in $\mathrm{AD}$ patients across populations [113]. Transcripts containing PTC variants are degraded by nonsense-mediated mRNA decay to avoid the formation of truncated proteins, resulting in LOF. A few pedigrees have been reported in which $A B C A 7$ PTC variants mimicking co-segregating with disease in an autosomal dominant inheritance $[114,115]$. For this reason, it is still debatable to consider these variants as high-penetrant mutations like APP, PSEN1, and PSEN2 mutations in AD. A few rare variants in GWASassociated genes are high-penetrant mutations, compared to the common single nucleotide polymorphisms (SNPs) detected in the association studies. Functional characterization of these rare variants is of major importance, because they exert a pathogenic effect on disease progression. Importantly, patients carrying these variants need genetic counseling as well as effective treatments.

\section{The potential of additional omics tools to provide insights into disease etiology}

Advances in other omics tools are contributing to increase understanding of unknown genetic causes, post-genomic effects, and molecular pathways of NBD. Among them, long-read sequencing (e.g., Oxford Nanopore Technology) enables the detection of structural variants [116], short tandem repeats (STR) [117], and variable number of tandem repeats (VNTRs) [118]. High-throughput RNA sequencing (RNA-seq) transcriptomics (e.g., single-cell and single-nuclei RNA-seq) can identify expression signatures potentially associated with disease pathology, providing important insights into potential subpopulations of cells directly involved in disease [119]. A study showed that the brain of carriers of rare pathogenic APP, PSEN1, or PSEN2 mutations presented with lower neuron and higher astrocyte relative proportions compared to sporadic AD patients [120]. Similarly, the $A P O E \varepsilon 4$ allele also showed decreased neuronal and increased astrocyte relative proportions compared to $\mathrm{AD}$ non-carriers, while carriers of rare TREM2 risk variants showed a lower degree of neuronal loss [120]. Proteomics approaches (e.g., spatial proteomics) also contributed to the unraveling of NBD pathogenesis, enabling localizations of proteins and their dynamics at the subcellular level [121]. Epigenetic changes also implicated in NBD pathogenesis have shown an increased methylation state in the promoter region of C9orf72 repeat expansion carriers [122]. Evidence suggests that metabolomic perturbations in different pathways may mediate the occurrence of NBD, as demonstrated by one of the largest metabolomics studies conducted by researchers from the Alzheimer's Disease Metabolomics Consortium [123]. These achievements demonstrate the potential of these alternative omics technologies to reveal complex events in relation to NBD.

\section{Conclusions and future directions}

NBD are devastating disorders with yet no current effective treatments. Advances in omics technologies facilitated an increased knowledge of the biological mechanisms underlying CNS neurodegeneration, based on the identification of novel genes and specific pathways contributing to NBD pathophysiology. These advances also increased the detection of rare VUS, of which functional analysis did not keep pace with the development of these methodologies. Understanding the post-genomic consequences of rare variants has direct implications in clinical practice. WGS is predicted to convert to the standard diagnostic tool in medical genetic testing within 5 years [124]. Considering the complexity of NBD, a profound understanding of the role of rare variants will be essential for the design of clinical trials, identifying people at high risk, personalized prevention, and treatment. Recent work demonstrated the potential of patient-derived iPSCs, in combination with genome editing technology and 3D brain organoids, in recapitulating the NBD phenotypes, which are presenting powerful tools for rare variant interpretation. The data generated from WES and WGS, in combination with the information provided by transcriptomics, proteomics, epigenomics, and metabolomics, will expand our understanding of the post-genomic effects of rare genetic variants and the disrupted pathways in NBD. Rare genetic variants in disease genes have received increased attention and their functional interpretation will provide a better understanding of disease pathogenesis, improvement of genetic diagnostic testing, clinical diagnosis, and development of therapeutics for personalized medicine in the future.

\footnotetext{
Abbreviations

3D: Three-dimensional; ABCA7: ATP-binding cassette sub-family A member 7; $\mathrm{AB}$ 13: $\mathrm{ABI}$ family member $3(A B / 3)$; $A C E$ : Angiotensin I-converting enzyme; ACMSD: Aminocarboxymuconate semialdehyde decarboxylase;

AD: Alzheimer's disease; ADAM10: ADAM metallopeptidase domain 10; ADAM TS1: ADAM metallopeptidase with thrombospondin type 1 motif 1; ADSP: Alzheimer Disease Sequencing Project; ALS: Amyotrophic lateral sclerosis; APOE: Apolipoprotein E; APP: Amyloid precursor protein; ASXL3: ASXL transcriptional regulator 3; ATP10B: ATPase phospholipid transporting 10B; A : Amyloid beta; BCKDK: Branched chain ketoacid dehydrogenase kinase; BIN1: Bridging integrator 1; BRIP1: BRCA1-interacting protein C-terminal helicase 1; BST1: Bone marrow stromal cell antigen 1; BTNL2: Butyrophilin like 2; C21orf2: Chromosome 21 open reading frame 2; C4orf27: Chromosome 4 open reading frame 27; C5orf24: Chromosome 5 open reading frame 24; C9orf72: Chromosome 9 open reading frame 72; CAB39L: Calcium-binding protein 39 like; CASS4: Cas scaffold protein family
} 
member 4; CCDC62: Coiled-coil domain containing 62; CD19: CD19 molecule; CD2AP: CD2-associated protein; CD33: Sialic acid-binding Ig-like lectin 3; CELF1: CUGBP Elav-like family member 1; CHRNB1: Cholinergic receptor nicotinic beta 1 subunit; CLCN3: Chloride voltage-gated channel 3; CLU: Clusterin; CNS: Central nervous system; CR1: Complement C3b/C4b receptor 1; CRLS1: Cardiolipin synthase 1; CSF: Cerebrospinal fluid; CTSC: Cathepsin C; CYLD: CYLD lysine 63 deubiquitinase; DDRGK1: DDRGK domain containing 1; DGKQ: Diacylglycerol kinase theta; DIANTU: Dominantly Inherited Alzheimer Network Trials Unit; DNAH17: Dynein axonemal heavy chain 17; DNM3: Dynamin-3; DPP6: Dipeptidyl peptidase like 6; DSG2: Desmoglein 2; DYRK1A: Dual-specificity tyrosine phosphorylation regulated kinase 1A; EPHA1: EPH receptor A1; ExAc: Exome Aggregation Consortium; FAM171A2: Family with sequence similarity 171 member A2; FAM47E: Family with sequence similarity 47 member E; FAM49B: CYFIP-related Rac1 interactor B; FBRSL1: Fibrosin like 1; FCGR2A: FC fragment of IgG receptor Ila; FERMT2: Fermitin family member 2; FGF20: Fibroblast growth factor 20; FGGY: FGGY carbohydrate kinase domain containing; FTD: Frontotemporal dementia; FUS: Fused in sarcoma; FYN: FYN proto-oncogene, Src family tyrosine kinase; GAK: Cyclin G-associated kinase; GBA: Beta acid glucosidase; GBF1: Golgi brefeldin A-resistant guanine nucleotide exchange factor 1; GPNMB: Glycoprotein nmb; GRN: Granulin; GWAS: Genome-wide association studies; HIP1: Huntingtin-interacting protein 1; HLA-DQA2: Major histocompatibility complex, class II, DQ alpha 2; HLA-DQB1: Major histocompatibility complex, class II, DQ beta 1; HLA-DRA: Major histocompatibility complex, class II, DR alpha; HLA-DRB1: Major histocompatibility complex, class II, DR beta 1; HLA-DRB5: Major histocompatibility complex, class II, DR beta 5; hPSCs: Human pluripotent stem cells; IFGC: International Frontotemporal Dementia Genomics Consortium; IGAP: International Genomics of Alzheimer's Project; IMMP2L: Inner mitochondrial membrane peptidase subunit 2; INPP5D: Inositol polyphosphate-5-phosphatase D; INPP5F: Inositol polyphosphate-5phosphatase F; IPDGC: International Parkinson's disease Genomics Consortium; iPSCs: Induced pluripotent stem cells; IQCK: IQ motif containing K; IRF2: Interferon regulatory factor 2; ITPR2: Inositol 1,4,5-trisphosphate receptor type 2; KAT8: Lysine acetyltransferase 8; KCNIP3: Potassium voltagegated channel interacting protein 3; KCNS3: Potassium voltage-gated channel modifier subfamily $\mathrm{S}$ member 3 ; KIF5A: Kinesin family member $5 \mathrm{~A}$; KPNA1: Karyopherin subunit alpha 1; LAMP3: Lysosomal-associated membrane protein 3; LCORL: Ligand-dependent nuclear receptor corepressor like; LINC00693: Long intergenic non-protein coding RNA 693; LOC101927354: na; LOC101927815: na; LOF: Loss-of-function; LRRK2: Leucine-rich repeat kinase 2; MAPT: Microtubule-associated protein tau; MBNL2: Muscleblind like splicing regulator 2; MCCC1: Methylcrotonoyl-CoA carboxylase 1; MED12L: Mediator complex subunit $12 \mathrm{~L}$; MEF2C: Myocyte enhancer factor 2C; MEX3C: mex-3 RNA binding family member C; MIPOL1: Mirror image polydactyly 1; MIR548AP: MicroRNA 548ap; MOBP: Myelin-associated oligodendrocyte basic protein; MS4A6A: Membrane spanning 4-domains A6A;

NBD: Neurodegenerative brain diseases; NGS: Next-generation sequencing; NME8: NME/NM23 family member 8; NOD2: Nucleotide-binding oligomerization domain containing 2; NUCKS: Nuclear casein kinase and cyclin-dependent kinase substrate 1; OLFM1: Olfactomedin 1; OPTN: Optineurin; PAM: Peptidylglycine alpha-amidating monooxygenase: PARK2: Parkin 2; PD: Parkinson's disease; PICALM: Phosphatidylinositol-binding clathrin assembly protein; PINK1: PTEN-induced kinase 1;

PLCG2: Phospholipase C Gamma 2; PRNP: Prion protein; PSEN1: Presenilin 1; PSEN2: Presenilin 2; PTC: Premature termination codon; PTK2B: Protein tyrosine kinase 2 beta; RAB29: RAB29, member RAS oncogene family; RAB38: RAB38, member RAS oncogene family; RA11: 1-Retinoic acid induced; RERG: RAS-like estrogen-regulated growth inhibitor; RIMS1: Regulating synaptic membrane exocytosis 1; RIT2: Ras-like without CAAX 2; RNAseq: RNA sequencing; RNF141: Ring finger protein 141; RPS12: Ribosomal protein S12; RPS6KL1: Ribosomal protein S6 kinase-like 1; SARM1: Sterile alpha and TIR motif containing 1; SCAF11: SR-related CTD-associated factor 11; SCARB2: Scavenger receptor class B member 2; SCFD1: sec1 family domain containing 1; SIPA1L2: Signal-induced proliferation-associated 1 like 2; SLC24A4: Solute carrier family 24 member 4; SNCA: a-Synuclein; SNPs: Singlenucleotide polymorphism; SOD1: Cu/Zn superoxide dismutase; SORL1: Sortilin-related receptor 1; SPTSSB: Serine palmitoyltransferase small subunit B; SQSTM1: Sequestosome 1; SREBF1: Sterol regulatory elementbinding transcription factor 1; STBD1: Starch-binding domain 1; STK39: Serine threonine kinase 39; STR: Short tandem repeat; STX1B: Syntaxin 1B;
SYT11: Synaptotagmin XI; TARDBP: TAR DNA-binding protein; TARDBP: Transactive response DNA-binding protein; TBK1: TANK-binding kinase 1 gene; TDP-43: TAR DNA-binding protein 43; TIA1: Cytotoxic granuleassociated RNA-binding protein; TMEM106B: Transmembrane protein 106B; TMEM163: Transmembrane protein 163; TMEM175: Transmembrane protein 175; TREM2: Triggering receptor expressed on myeloid cells; TRIM40: Tripartite motif containing 40; UBAP2: Ubiquitin-associated protein 2; UBTF: Upstream binding transcription factor; UNC13A: unc-13 homolog A; VAMP4: Vesicleassociated membrane protein 4; VCP: Valosin-containing protein gene; VNTR: Variable number of tandem repeats; VPS13C: Vacuolar protein sorting 13 homolog C; VUS: Variants of uncertain significance; WES: Whole-exome sequencing; WGS: Whole-genome sequencing; WWOX: WW domaincontaining oxidoreductase; ZCWPW1: Zinc finger CW-type and PWWP domain containing

\section{Authors' contributions}

FP contributed to the conception of the review paper, the design of the paper, the acquisition of the literature data, and the revision of the paper. $\mathrm{RC}$ contributed to the conception of the review paper, the design of the paper, the acquisition of the literature data, and the drafting and revision of the paper.

$J v d Z$ contributed to the drafting and revision of the paper.

CVB contributed to the conception of the review paper, the design of the paper, the acquisition of literature data, and the revision of the paper drafting.

All four authors approved the submitted final version and agreed to be personally accountable for the author's own contributions and to ensure that questions related to the accuracy or integrity of any part of the work, even ones in which the author was not personally involved, are appropriately investigated, resolved, and the resolution documented in the literature.

\section{Funding}

No funding was received for this review paper.

\section{Availability of data and materials Not applicable.}

\section{Declarations}

Ethics approval and consent to participate

Not applicable.

\section{Consent for publication}

Not applicable.

\section{Competing interests}

The authors declare that they have no competing interests.

Received: 4 November 2019 Accepted: 25 March 2021

Published online: 14 April 2021

\section{References}

1. Li KW, Ganz AB, Smit AB. Proteomics of neurodegenerative diseases: analysis of human post-mortem brain. J Neurochem. 2019;151:435-45.

2. Lee H, Mistry D, Smith T, Finnegan S, Fordham B, Sheehan B, et al. Mechanisms to reduce the burden on dementia caregivers. SSRN Electron J. Elsevier BV; 2020;

3. Van Broeckhoven C, Backhovens H, Cruts M, De Winter G, Bruyland M, Cras $P$, et al. Mapping of a gene predisposing to early-onset Alzheimer's disease to chromosome 14q24.3. Nat Genet. 1992;2:335-9.

4. Polymeropoulos MH, Lavedan C, Leroy E, Ide SE, Dehejia A, Dutra A, Pike B, Root H, Rubenstein J, Boyer R, Stenroos ES, Chandrasekharappa S, Athanassiadou A, Papapetropoulos T, Johnson WG, Lazzarini AM, Duvoisin RC, di lorio G, Golbe LI, Nussbaum RL. Mutation in the alpha-synuclein gene identified in families with Parkinson's disease. Science. 1997;276(5321):20457. https://doi.org/10.1126/science.276.5321.2045.

5. Van Broeckhoven C, Haan J, Bakker E, Hardy JA, Van Hul W, Wehnert A, et al Amyloid beta protein precursor gene and hereditary cerebral hemorrhage with amyloidosis (Dutch). Science. 1990;248(4959):1120-2. https://doi.org/1 $0.1126 /$ science. 1971458 . 
6. Levy-Lahad E, Wasco W, Poorkaj P, Romano DM, Oshima J, Pettingell WH, Yu C, Jondro P, Schmidt S, Wang K. Candidate gene for the chromosome 1 familial Alzheimer's disease locus. Science. 1995;269(5226):973-7. https://doi. org/10.1126/science.7638622.

7. Jayadev S, Nochlin D, Poorkaj P, Steinbart EJ, Mastrianni JA, Montine TJ, et al. Familial prion disease with Alzheimer disease-like tau pathology and clinical phenotype. Ann Neurol. 2011;69:712-20.

8. Kitada T, Asakawa S, Hattori N, Matsumine H, Yamamura Y, Minoshima S, et al. Mutations in the parkin gene cause autosomal recessive juvenile parkinsonism. Nature. 1998;392:605-8.

9. Paisán-Ruíz C, Jain S, Evans EW, Gilks WP, Simón J, van der Brug M, et al. Cloning of the gene containing mutations that cause PARK8-linked Parkinson's disease. Neuron.; 2004:44:595-600.

10. Cruts M, Gijselinck I, van der Zee J, Engelborghs S, Wils H, Pirici D, Rademakers R, Vandenberghe R, Dermaut B, Martin JJ, van Duijn C, Peeters K, Sciot R, Santens P, de Pooter T, Mattheijssens M, van den Broeck M, Cuijt I, Vennekens K', de Deyn PP, Kumar-Singh S, van Broeckhoven C. Null mutations in progranulin cause ubiquitin-positive frontotemporal dementia linked to chromosome 17q21. Nature. 2006;442(7105):920-4. https://doi. org/10.1038/nature05017.

11. Hutton M, Lendon CL, Rizzu P, Baker M, Froelich S, Houlden H, et al. Association of missense and $5^{\prime}$-splice-site mutations in tau with the inherited dementia FTDP-17. Nature. 1998;393:702-5.

12. Kwiatkowski TJ, Bosco DA, Leclerc AL, Tamrazian E, Vanderburg CR, Russ C, et al. Mutations in the FUS/TLS gene on chromosome 16 cause familial amyotrophic lateral sclerosis. Science. 2009;323(5918):1205-8. https://doi. org/10.1126/science.1166066.

13. Rosen DR, Siddique T, Patterson D, Figlewicz DA, Sapp P, Hentati A, et al. Mutations in $\mathrm{Cu} / \mathrm{Zn}$ superoxide dismutase gene are associated with familial amyotrophic lateral sclerosis. Nature. 1993;362:59-62.

14. Sreedharan J, Blair IP, Tripathi VB, Hu X, Vance C, Rogelj B, et al. TDP-43 mutations in familial and sporadic amyotrophic lateral sclerosis. Science (80). 2008:319:1668-72.

15. DeJesus-Hernandez M, Mackenzie IR, Boeve BF, Boxer AL, Baker M, Rutherford NJ, Nicholson AM, Finch NCA, Flynn H, Adamson J, Kouri N, Wojtas A, Sengdy P, Hsiung GYR, Karydas A, Seeley WW, Josephs KA, Coppola G, Geschwind DH, Wszolek ZK, Feldman H, Knopman DS, Petersen RC, Miller BL, Dickson DW, Boylan KB, Graff-Radford NR, Rademakers R. Expanded GGGGCC hexanucleotide repeat in noncoding region of C9ORF72 causes chromosome 9p-linked FTD and ALS. Neuron. 2011;72(2): 245-56. https://doi.org/10.1016/j.neuron.2011.09.011.

16. Cirulli ET, Lasseigne BN, Petrovski S, Sapp PC, Dion A, Leblond CS, et al. Exome sequencing in amyotrophic lateral sclerosis identifies risk genes and pathways 2015;62:1-12.

17. Gijselinck I, Van Mossevelde S, van der Zee, Sieben A, Philtjens S, Heeman B et al. Loss of TBK1 is a frequent cause of frontotemporal dementia in a Belgian cohort Neurology. 2015;85(24):2116-25. https://doi.org/10.1212/ WNL.0000000000002220. Epub 2015 Nov 18.

18. Pottier C, Bieniek KF, Finch NC, van de Vorst M, Baker M, Perkersen $R$, et al. Whole-genome sequencing reveals important role for TBK1 and OPTN mutations in frontotemporal lobar degeneration without motor neuron disease. Acta Neuropathol. 2015;130:77-92.

19. Kimonis VE, Mehta SG, Fulchiero EC, Thomasova D, Pasquali M, Boycott $K$, et al. Clinical studies in familial VCP myopathy associated with Paget disease of bone and frontotemporal dementia. Am J Med Genet Part A. 2008;146A: $745-57$

20. Sierksma A, Lu A, Salta E, Mancuso R, Zoco J, Blum D, et al. Novel Alzheimer risk genes determine the microglia response to amyloid- $\beta$ but not to TAU pathology. EMBO Mol Med. 2020;12(3):e10606. https://doi.org/10.15252/ emmm.201910606. Epub 2020 Jan 17.

21. Pottier $C$, Ren $Y$, Perkerson RB, Baker M, Jenkins GD, van Blitterswijk M, et al. Genome wide analyses as part of the international FTLD-TDP wholegenome sequencing consortium reveals novel disease risk factors and increases support for immune dysfunction in FTLD. Acta Neuropathol; 2019;137(6): 879-99. https://doi.org/10.1007/s00401-019-01962-9. Epub 2019 Feb 9.

22. Nalls MA, Blauwendraat $C$, Vallerga $C L$, Heilbron $K$, Bandres-Ciga S, Chang D, Tan M, Kia DA, Noyce AJ, Xue A, Bras J, Young E, von Coelln R, SimónSánchez J, Schulte C, Sharma M, Krohn L, Pihlstrøm L, Siitonen A, Iwaki H, Leonard H, Faghri F, Gibbs JR, Hernandez DG, Scholz SW, Botia JA, Martinez M, Corvol JC, Lesage S, Jankovic J, Shulman LM, Sutherland M, Tienari P, Majamaa K, Toft M, Andreassen OA, Bangale T, Brice A, Yang J, Gan-Or Z,
Gasser T, Heutink P, Shulman JM, Wood NW, Hinds DA, Hardy JA, Morris HR, Gratten J, Visscher PM, Graham RR, Singleton AB, Adarmes-Gómez AD, Aguilar M, Aitkulova A, Akhmetzhanov V, Alcalay RN, Alvarez I, Alvarez V, Bandres-Ciga S, Barrero FJ, Bergareche Yarza JA, Bernal-Bernal I, Billingsley K, Blauwendraat C, Blazquez M, Bonilla-Toribio M, Botía JA, Boungiorno MT, Bras J, Brice A, Brockmann K, Bubb V, Buiza-Rueda D, Cámara A, Carrillo F, Carrión-Claro M, Cerdan D, Chelban V, Clarimón J, Clarke C, Compta Y, Cookson MR, Corvol JC, Craig DW, Danjou F, Diez-Fairen M, Dols-Icardo O, Duarte J, Duran R, Escamilla-Sevilla F, Escott-Price V, Ezquerra M, Faghri F, Feliz C, Fernández M, Fernández-Santiago R, Finkbeiner S, Foltynie T, Gan-Or Z, Garcia C, García-Ruiz P, Gasser T, Gibbs JR, Gomez Heredia MJ, GómezGarre P, González MM, Gonzalez-Aramburu I, Guelfi S, Guerreiro R, Hardy J, Hassin-Baer S, Hernandez DG, Heutink P, Hoenicka J, Holmans P, Houlden H, Infante J, Iwaki H, Jesús S, Jimenez-Escrig A, Kaishybayeva G, Kaiyrzhanov R, Karimova A, Kia DA, Kinghorn KJ, Koks S, Krohn L, Kulisevsky J, LabradorEspinosa MA, Leonard HL, Lesage S, Lewis P, Lopez-Sendon JL, Lovering R, Lubbe S, Lungu C, Macias D, Majamaa K, Manzoni C, Marín J, Marinus J, Marti MJ, Martinez M, Martínez Torres I, Martínez-Castrillo JC, Mata M, Mencacci NE, Méndez-del-Barrio C, Middlehurst B, Mínguez A, Mir P, Mok KY, Morris HR, Muñoz E, Nalls MA, Narendra D, Noyce AJ, Ojo OO, Okubadejo NU, Pagola AG, Pastor P, Perez Errazquin F, Periñán-Tocino T, Pihlstrom L, Plun-Favreau H, Quinn J, R'Bibo L, Reed X, Rezola EM, Rizig M, Rizzu P, Robak L, Rodriguez AS, Rouleau GA, Ruiz-Martínez J, Ruz C, Ryten M, Sadykova D, Scholz SW, Schreglmann S, Schulte C, Sharma M, Shashkin C, Shulman JM, Sierra M, Siitonen A, Simón-Sánchez J, Singleton AB, SuarezSanmartin E, Taba P, Tabernero C, Tan MX, Tartari JP, Tejera-Parrado C, Toft M, Tolosa E, Trabzuni D, Valldeoriola F, van Hilten JJ, van Keuren-Jensen K, Vargas-González L, Vela L, Vives F, Williams N, Wood NW, Zharkinbekova N, Zharmukhanov Z, Zholdybayeva E, Zimprich A, Ylikotila P, Shulman LM, von Coelln R, Reich S, Savitt J, Agee M, Alipanahi B, Auton A, Bell RK, Bryc K, Elson SL, Fontanillas P, Furlotte NA, Huber KE, Hicks B, Jewett EM, Jiang Y, Kleinman A, Lin KH, Litterman NK, McCreight JC, Mclntyre MH, McManus KF, Mountain JL, Noblin ES, Northover CAM, Pitts SJ, Poznik GD, Sathirapongsasuti JF, Shelton JF, Shringarpure S, Tian C, Tung J, Vacic V, Wang X, Wilson CH, Anderson T, Bentley S, Dalrymple-Alford J, Fowdar J, Gratten J, Halliday G, Henders AK, Hickie I, Kassam I, Kennedy M, Kwok J, Lewis S, Mellick G, Montgomery G, Pearson J, Pitcher T, Sidorenko J, Silburn PA, Vallerga CL, Visscher PM, Wallace L, Wray NR, Xue A, Yang J, Zhang F. Identification of novel risk loci, causal insights, and heritable risk for Parkinson's disease: a meta-analysis of genome-wide association studies. Lancet Neurol. 2019;18(12):1091-102. https://doi.org/10.1016/S1474-4422 (19)30320-5.

23. Nicolas A, Kenna KP, Renton AE, Ticozzi N, Faghri F, Chia R, et al. Genomewide analyses identify KIF5A as a novel ALS gene. Neuron; 2018;97:12681283.e6.

24. Lambert J-C, Heath S, Even G, Campion D, Sleegers K, Hiltunen M, et al. Genome-wide association study identifies variants at CLU and CR1 associated with Alzheimer's disease. Nat Genet. 2009:41(10):1094-9. https:// doi.org/10.1038/ng.439.

25. Harold D, Abraham R, Hollingworth P, Sims R, Gerrish A, Hamshere ML, et al. Genome-wide association study identifies variants at CLU and PICALM associated with Alzheimer's disease. Nat Genet. 2009:41:1088-93.

26. Hollingworth P, Harold D, Sims R, Gerrish A, Lambert J-C, Carrasquillo MM, et al. Common variants at ABCA7, MS4A6A/MS4A4E, EPHA1, CD33 and CD2AP are associated with Alzheimer's disease. Nat Genet Nature Research. 2011:43(5):429-35. https://doi.org/10.1038/ng.803.

27. Reitz C, Jun G, Naj A, Rajbhandary R, Vardarajan BN, Wang L-S, Valladares O, Lin CF, Larson EB, Graff-Radford NR, Evans D, de Jager PL, Crane PK, Buxbaum JD, Murrell JR, Raj T, Ertekin-Taner N, Logue M, Baldwin CT, Green RC, Barnes LL, Cantwell LB, Fallin MD, Go RCP, Griffith P, Obisesan TO, Manly JJ, Lunetta KL, Kamboh MI, Lopez OL, Bennett DA, Hendrie H, Hall KS, Goate AM, Byrd GS, Kukull WA, Foroud TM, Haines JL, Farrer LA, Pericak-Vance MA, Schellenberg GD, Mayeux R, Alzheimer Disease Genetics Consortium. Variants in the ATP-binding cassette transporter (ABCA7), apolipoprotein E $\in 4$, and the risk of late-onset Alzheimer disease in African Americans. JAMA. 2013;309(14):1483-92. https://doi.org/10.1001/jama.2013.2973.

28. Lambert J-C, Ibrahim-Verbaas CA, Harold D, Naj AC, Sims R, Bellenguez C, et al. Meta-analysis of 74,046 individuals identifies 11 new susceptibility loci for Alzheimer's disease. Nat Genet 2013; 2013;45:1452.

29. Kunkle BW, Grenier-Boley B, Sims R, Bis JC, Damotte V, Naj AC, et al. Genetic meta-analysis of diagnosed Alzheimer's disease identifies new risk loci and 
implicates $A \beta$, tau, immunity and lipid processing. Nat Genet. 2019;51(3): 414-30. https://doi.org/10.1038/s41588-019-0358-2

30. Marioni RE, Harris SE, Zhang Q, Mcrae AF, Hagenaars SP, David Hill W, et al. GWAS on family history of Alzheimer's disease. Transl Psychiatry. 2018;8(1): 99. https://doi.org/10.1038/s41398-018-0150-6.

31. Singleton A. Imputation of sequence variants for identification of genetic risks for Parkinson's disease: a meta-analysis of genome-wide association studies. Lancet. 2011;377:641-9.

32. Nalls MA, Pankratz N, Lill CM, Do CB, Hernandez DG, Saad M, et al. Largescale meta-analysis of genome-wide association data identifies six new risk loci for Parkinson's disease. Nat Genet. 2014;46:989-93.

33. Simón-Sánchez J, Schulte C, Bras JM, Sharma M, Gibbs JR, Berg D, PaisanRuiz C, Lichtner P, Scholz SW, Hernandez DG, Krüger R, Federoff M, Klein C, Goate A, Perlmutter J, Bonin M, Nalls MA, Illig T, Gieger C, Houlden H, Steffens M, Okun MS, Racette BA, Cookson MR, Foote KD, Fernandez HH, Traynor BJ, Schreiber S, Arepalli S, Zonozi R, Gwinn K, van der Brug M, Lopez G, Chanock SJ, Schatzkin A, Park Y, Hollenbeck A, Gao J, Huang X, Wood NW, Lorenz D, Deuschl G, Chen H, Riess O, Hardy JA, Singleton AB, Gasser T. Genome-wide association study reveals genetic risk underlying Parkinson's disease. Nat Genet. 2009;41(12):1308-12. https://doi.org/10.1038/ng.487.

34. Van Deerlin VM, Sleiman PMA, Martinez-Lage M, Chen-Plotkin A, Wang L-S, Graff-Radford NR, et al. Common variants at 7p21 are associated with frontotemporal lobar degeneration with TDP-43 inclusions. Nat Genet. 2010; 42(3):234-9. https://doi.org/10.1038/ng.536.

35. van Rheenen W, Shatunov A, Dekker AM, McLaughlin RL, Diekstra FP, Pulit SL, et al. Genome-wide association analyses identify new risk variants and the genetic architecture of amyotrophic lateral sclerosis. Nat Genet. 2016;48: 1043-8

36. Fogh I, Ratti A, Gellera C, Lin K, Tiloca C, Moskvina V, et al. A genome-wide association meta-analysis identifies a novel locus at 17q11.2 associated with sporadic amyotrophic lateral sclerosis. Hum Mol Genet. 2014;23:2220-31.

37. Ciani M, Bonvicini C, Scassellati C, Carrara M, Maj C, Fostinelli S, et al. The missing heritability of sporadic frontotemporal dementia: new insights from rare variants in neurodegenerative candidate genes. Int J Mol Sci. 2019;20: 3903.

38. Giau V, Senanarong V, Bagyinszky E, An S, Kim S. Analysis of 50 neurodegenerative genes in clinically diagnosed early-onset Alzheimer's disease. Int J Mol Sci. 2019;20:1514.

39. Smolders S, Van Broeckhoven C. Genetic perspective on the synergistic connection between vesicular transport, lysosomal and mitochondrial pathways associated with Parkinson's disease pathogenesis. Acta Neuropathol. Commun; 2020;8(1):63. https://doi.org/10.1186/s40478-02000935-4.

40. Baradaran-Heravi Y, Van Broeckhoven C, van der Zee J. Stress granule mediated protein aggregation and underlying gene defects in the FTD-ALS spectrum. Neurobiol. Dis; 2020;134:104639. https://doi.org/10.1016/j.nbd.201 9.104639.

41. Boycott KM, Vanstone MR, Bulman DE, MacKenzie AE. Rare-disease genetics in the era of next-generation sequencing: discovery to translation. Nat Publ Gr. 2013;14

42. Ciani M, Benussi L, Bonvicini C, Ghidoni R. Genome wide association study and next generation sequencing: a glimmer of light toward new possible horizons in frontotemporal dementia research. Front Neurosci. 2019;13:506.

43. Ramos-Campoy O, Antonell A, Falgàs N, Balasa M, Borrego-Écija S, Rodríguez-Santiago $B$, et al. Screening of dementia genes by whole-exome sequencing in Spanish patients with early-onset dementia: likely pathogenic, uncertain significance and risk variants. Neurobiol Aging; 2020 93:e1-e9. https://doi.org/10.1016/j.neurobiolaging.2020.02.008. Epub 2020 Feb 18.

44. Pecoraro V, Mandrioli J, Carone C, Chiò A, Traynor BJ, Trenti T. The NGS technology for the identification of genes associated with the ALS. A systematic review. Eur J Clin Invest. 2020;50:e13228.

45. Kircher M, Witten DM, Jain P, O'Roak BJ, Cooper GM, Shendure J. A general framework for estimating the relative pathogenicity of human genetic variants. Nat Genet. 2014;46(3):310-5. https://doi.org/10.1038/ng.2892.

46. Eilbeck K, Quinlan A, Yandell M. Settling the score: variant prioritization and Mendelian disease. Nat Rev Genet. 2017;18(10):599-612. https://doi.org/10.1 038/nrg.2017.52

47. Diaz-Ortiz ME, Chen-Plotkin AS. Omics in neurodegenerative disease: hope or hype? Trends Genet.; 2020;36(3):152-9. https://doi.org/10.1016/j.tig.201 9.12.002. Epub 2020 Jan 10
48. Guo MH, Plummer L, Chan Y-M, Hirschhorn JN, Lippincott MF. Burden testing of rare variants identified through exome sequencing via publicly available control data. Am J Hum Genet. 2018;103(4):522-34. https://doi. org/10.1016/j.ajhg.2018.08.016

49. Martin S, Smolders S, Van den Haute C, Heeman B, van Veen S, Crosiers D, et al. Mutated ATP10B increases Parkinson's disease risk by compromising lysosomal glucosylceramide export. Acta Neuropathol. 2020;139(6):1001-24. https://doi.org/10.1007/s00401-020-02145-7. Epub 2020 Mar 14.

50. Cacace R, Sleegers K, Van Broeckhoven C. Molecular genetics of early-onset Alzheimer disease revisited. Alzheimer's Dement. 2016;12(6):733-48. https:// doi.org/10.1016/j.jalz.2016.01.012. Epub 2016 Mar 24.

51. Carmona S, Zahs K, Wu E, Dakin K, Bras J, Guerreiro R. The role of TREM2 in Alzheimer's disease and other neurodegenerative disorders. Lancet Neurol; 2018;17(8):721-30. https://doi.org/10.1016/S1474-4422(18)30232-1. Epub 2018 Jul 17.

52. Sims R, van der Lee SJ, Naj AC, Bellenguez C, Badarinarayan N, Jakobsdottir J, et al. Rare coding variants in PLCG2, ABI3, and TREM2 implicate microglial-mediated innate immunity in Alzheimer's disease. Nat Genet. 2017:49(9):1373-84. https://doi.org/10.1038/ng.3916.

53. Grünewald A, Kumar KR, Sue CM. New insights into the complex role of mitochondria in Parkinson's disease. Prog. Neurobiol.; 2019;177:73-93. https://doi.org/10.1016/j.pneurobio.2018.09.003. Epub 2018 Sep 13.

54. Lesage S, Drouet V, Majounie E, Deramecourt V, Jacoupy M, Nicolas A, Cormier-Dequaire F, Hassoun SM, Pujol C, Ciura S, Erpapazoglou Z, Usenko T, Maurage CA, Sahbatou M, Liebau S, Ding J, Bilgic B, Emre M, ErginelUnaltuna N, Guven G, Tison F, Tranchant C, Vidailhet M, Corvol JC, Krack P, Leutenegger AL, Nalls MA, Hernandez DG, Heutink P, Gibbs JR, Hardy J, Wood NW, Gasser T, Durr A, Deleuze JF, Tazir M, Destée A, Lohmann E, Kabashi $E$, Singleton A, Corti O, Brice A, Lesage S, Tison F, Vidailhet M, Corvol JC, Agid Y, Anheim M, Bonnet AM, Borg M, Broussolle E, Damier P, Destée A, Dürr A, Durif F, Krack P, Klebe S, Lohmann E, Martinez M, Pollak P, Rascol O, Tranchant C, Vérin M, Viallet F, Brice A, Lesage S, Majounie E, Tison F, Vidailhet M, Corvol JC, Nalls MA, Hernandez DG, Gibbs JR, Dürr A, Arepalli S, Barker RA, Ben-Shlomo Y, Berg D, Bettella F, Bhatia K, de Bie RMA, Biffi A, Bloem BR, Bochdanovits Z, Bonin M, Lesage S, Tison F, Vidailhet M, Corvol JC, Agid Y, Anheim M, Bonnet AM, Borg M, Broussolle E, Damier P, Destée A, Dürr A, Durif F, Krack P, Klebe S, Lohmann E, Martinez M, Pollak P, Rascol O, Tranchant C, Vérin M, Bras JM, Brockmann K, Brooks J, Burn DJ, Charlesworth G, Chen H, Chinnery PF, Chong S, Clarke CE, Cookson MR, Counsell C, Damier P, Dartigues JF, Deloukas P, Deuschl G, Dexter DT, van Dijk KD, Dillman A, Dong J, Durif F, Edkins S, Escott-Price V, Evans JR, Foltynie T, Gao J, Gardner M, Goate A, Gray E, Guerreiro R, Harris C, van Hilten JJ, Hofman A, Hollenbeck A, Holmans P, Holton J, Hu M, Huang X, Huber H, Hudson G, Hunt SE, Huttenlocher J, Illig T, Jónsson PV, Kilarski LL, Jansen IE, Lambert JC, Langford C, Lees A, Lichtner P, Limousin P, Lopez G, Lorenz D, Lubbe S, Lungu C, Martinez M, Mätzler W, McNeill A, Moorby C, Moore M, Morrison KE, Mudanohwo E, O'Sullivan SS, Owen MJ, Pearson J, Perlmutter JS, Pétursson H, Plagnol V, Pollak P, Post B, Potter S, Ravina B, Revesz T, Riess O, Rivadeneira F, Rizzu P, Ryten M, Saad M, Simón-Sánchez J, Sawcer S, Schapira A, Scheffer H, Schulte C, Sharma M, Shaw K, Sheerin UM, Shoulson I, Shulman J, Sidransky E, Spencer CCA, Stefánsson H, Stefánsson K, Stockton JD, Strange A, Talbot K, Tanner CM, Tashakkori-Ghanbaria A Trabzuni D, Traynor BJ, Uitterlinden AG, Velseboer D, Walker $R$, van de Warrenburg B, Wickremaratchi M, Williams-Gray CH, Winder-Rhodes S, Wurster I, Williams N, Morris HR, Heutink P, Hardy J, Wood NW, Gasser T, Singleton $A B$, Brice $A$. Loss of VPS13C function in autosomal-recessive parkinsonism causes mitochondrial dysfunction and increases PINK1/Parkindependent mitophagy. Am J Hum Genet. 2016;98(3):500-13. https://doi. org/10.1016/j.ajhg.2016.01.014.

55. Mackenzie IR, Nicholson AM, Boylan KB, Taylor JP, Rademakers CR. TIA1 mutations in amyotrophic lateral sclerosis and frontotemporal dementia promote phase separation and alter stress granule dynamics in brief; 2017.

56. Hackman P, Sarparanta J, Lehtinen S, Vihola A, Evilä A, Jonson PH, et al. Welander distal myopathy is caused by a mutation in the RNA-binding protein TIA1. Ann Neurol. 2013;73:500-9.

57. Martini-Stoica $H, X u$ Y, Ballabio A, Zheng H. The autophagy-lysosomal pathway in neurodegeneration: a TFEB perspective. Trends Neurosci. 2016; 39(4):221-34. https://doi.org/10.1016/j.tins.2016.02.002.

58. Gijselinck I, Mossevelde S Van, Van C, Van Mossevelde S, van der Zee J, Sieben $A$, et al. Loss of TBK1 is a frequent cause of frontotemporal dementia in a Belgian cohort. Neurology; 2015;0:2116-2125. 
59. Dobson-Stone C, Hallupp M, Shahheydari H, Ragagnin AMG, Chatterton Z, Carew-Jones F, et al. CYLD is a causative gene for frontotemporal dementia - amyotrophic lateral sclerosis. Brain. 2020;143:783-99.

60. Perrone F, Cacace R, Van Mossevelde S, Van den Bossche T, De Deyn PP, Cras $P$, et al. Genetic screening in early-onset dementia patients with unclear phenotype: relevance for clinical diagnosis. Neurobiol Aging; 2018; 69:292.e7-292.e14

61. Ferrari R, Wang Y, Vandrovcova J, Guelfi S, Witeolar A, Karch CM, et al. Genetic architecture of sporadic frontotemporal dementia and overlap with Alzheimer's and Parkinson's diseases. J Neurol Neurosurg Psychiatry P Momeni. 2017:88:152-64.

62. Gossye H, Van Broeckhoven C, Engelborghs S. The use of biomarkers and genetic screening to diagnose frontotemporal dementia: evidence and clinical implications. Front Genet. 2019;10:757.

63. Young AL, Marinescu RV, Oxtoby NP, Bocchetta M, Yong K, Firth NC, et al. Uncovering the heterogeneity and temporal complexity of neurodegenerative diseases with subtype and stage inference. Nat Commun. 2018;9:4273

64. James BD, Wilson RS, Boyle PA, Trojanowski JQ, Bennett DA, Schneider JA TDP-43 stage, mixed pathologies, and clinical Alzheimer's-type dementia. Brain Narnia. 2016;139(11):2983-93. https://doi.org/10.1093/brain/aww224.

65. Rademakers R, Dermaut B, Peeters K, Cruts M, Heutink P, Goate A, et al. Tau (MAPT) mutation Arg406Trp presenting clinically with Alzheimer disease does not share a common founder in Western Europe [1]. Hum Mutat. 2003:22:409-11.

66. Coppola G, Chinnathambi S, Lee JJY, Dombroski BA, Baker MC, Soto-ortolaza $\mathrm{Al}$, et al. Evidence for a role of the rare p.A152T variant in mapt in increasing the risk for FTD-spectrum and Alzheimer's diseases. Hum Mol Genet. 2012;21:3500-12.

67. Barber IS, Braae A, Clement N, Patel T, Guetta-Baranes T, Brookes K, et al. Mutation analysis of sporadic early-onset Alzheimer's disease using the NeuroX array. Neurobiol Aging. 2017;49:215.e1-215.e8. https://doi.org/10.101 6/j.neurobiolaging.2016.09.008. Epub 2016 Sep 23.

68. Wauters E, Van Mossevelde S, Sleegers K, van der Zee J, Engelborghs S, Sieben A, et al. Clinical variability and onset age modifiers in an extended Belgian GRN founder family. Neurobiol Aging. 2018;67:84-94. https://doi. org/10.1016/j.neurobiolaging.2018.03.007.

69. Saghira C, Bis DM, Stanek D, Strickland A, Herrmann DN, Reilly MM, Scherer SS, Shy ME, Inherited Neuropathy Consortium, Züchner S. Variant pathogenicity evaluation in the community-driven Inherited Neuropathy Variant Browser. Hum Mutat. 2018;39(5):635-42. https://doi.org/10.1002/humu.23412.

70. Carrieri D, Howard HC, Benjamin C, Clarke AJ, Dheensa S, Doheny S, et al. Recontacting patients in clinical genetics services: recommendations of the European Society of Human Genetics. Eur J Hum Genet. 2019;27(2):169-82. https://doi.org/10.1038/s41431-018-0285-1.

71. Bateman RJ, Benzinger TL, Berry S, Clifford DB, Duggan C, Fagan AM, et al. The DIAN-TU Next Generation Alzheimer's prevention trial: adaptive design and disease progression model. Alzheimer's Dement. 2017;13:8-19.

72. Charvin D, Medori R, Hauser RA, Rascol O. Therapeutic strategies for Parkinson disease: beyond dopaminergic drugs. Nat Rev Drug Discov. 2018; 17(11):804-22. https://doi.org/10.1038/nrd.2018.136.

73. Pang SY-Y, Teo K-C, Hsu JS, Chang RS-K, Li M, Sham P-C, Ho SL. The role of gene variants in the pathogenesis of neurodegenerative disorders as revealed by next generation sequencing studies: a review. Transl Neurodegener. 2017;6(1):27. https://doi.org/10.1186/s40035-017-0098-0.

74. Nelson PT, Dickson DW, Trojanowski JQ, Jack CR, Boyle PA, Arfanakis K, Rademakers R, Alafuzoff I, Attems J, Brayne C, Coyle-Gilchrist ITS, Chui HC, Fardo DW, Flanagan ME, Halliday G, Hokkanen SRK, Hunter S, Jicha GA, Katsumata Y, Kawas CH, Keene CD, Kovacs GG, Kukull WA, Levey Al, Makkinejad N, Montine TJ, Murayama S, Murray ME, Nag S, Rissman RA, Seeley WW, Sperling RA, White III CL, Yu L, Schneider JA. Limbicpredominant age-related TDP-43 encephalopathy (LATE): consensus working group report. Brain. 2019;142(6):1503-27. https://doi.org/10.1093/ brain/awz099.

75. Haston KM, Finkbeiner S. Clinical trials in a dish: the potential of pluripotent stem cells to develop therapies for neurodegenerative diseases. Annu Rev Pharmacol Toxicol. 2016;56(1):489-510. https://doi.org/10.1146/annurev-pha rmtox-010715-103548.

76. Budde JP, Martinez R, Hsu S, Wen N, Chen JA, Coppola G, et al. Precision genome-editing with CRISPR/Cas9 in human induced pluripotent stem cells. bioRxiv; 2017;187377. https://doi.org/10.1101/187377.
77. Hu X, Mao C, Fan L, Luo H, Hu Z, Zhang S, et al. Modeling Parkinson's disease using induced pluripotent stem cells. Anna S, editor. Stem Cells Int. 2020;2020:1061470.

78. Chang CY, Ting HC, Liu CA, Su HL, Chiou TW, Lin SZ, et al. Induced pluripotent stem cell (iPSC)-based neurodegenerative disease models for phenotype recapitulation and drug screening. Molecules; 2020;25(8):2000. https://doi.org/10.3390/molecules25082000.

79. Lee C-T, Bendriem RM, Wu WW, Shen R-F. 3D brain organoids derived from pluripotent stem cells: promising experimental models for brain development and neurodegenerative disorders. J Biomed Sci. 2017;24:59.

80. Raja WK, Mungenast AE, Lin Y-T, Ko T, Abdurrob F, Seo J, et al. Selforganizing 3D human neural tissue derived from induced pluripotent stem cells recapitulate Alzheimer's disease phenotypes. Padmanabhan J, editor. PLoS One.; 2016;11:e0161969.

81. Wauters E, Van Mossevelde S, Van der Zee J, Cruts M, Van Broeckhoven C. Modifiers of GRN-associated frontotemporal lobar degeneration. Trends Mol Med. 2017;23:962-79.

82. Shankaran SS, Capell A, Hruscha AT, Fellerer K, Neumann M, Schmid B, et al. Missense mutations in the progranulin gene linked to frontotemporal lobar degeneration with ubiquitin-immunoreactive inclusions reduce progranulin production and secretion. J Biol Chem. 2008;283:1744-53.

83. Kleinberger G, Capell A, Brouwers N, Fellerer K, Sleegers K, Cruts M, et al. Reduced secretion and altered proteolytic processing caused by missense mutations in progranulin. Neurobiol Aging. 2016;39:220. e17-220.e26

84. Freischmidt A, Wieland T, Richter B, Ruf W, Schaeffer V, Müller K, Marroquin N, Nordin F, Hübers A, Weydt P, Pinto S, Press R, Millecamps S, Molko N, Bernard E, Desnuelle C, Soriani MH, Dorst J, Graf E, Nordström U, Feiler MS, Putz S, Boeckers TM, Meyer T, Winkler AS, Winkelman J, de Carvalho M, Thal DR, Otto M, Brännström T, Volk AE, Kursula P, Danzer KM, Lichtner P, Dikic I, Meitinger T, Ludolph AC, Strom TM, Andersen PM, Weishaupt JH. Haploinsufficiency of TBK1 causes familial ALS and fronto-temporal dementia. Nat Neurosci. 2015;18(5):631-6. https://doi.org/10.1038/nn.4000.

85. van der Zee J, Gijselinck I, Van Mossevelde S, Perrone F, Dillen L, Heeman B, et al. TBK1 mutation spectrum in an extended European patient cohort with frontotemporal dementia and amyotrophic lateral sclerosis. Hum Mutat. 2016:1-13.

86. de Majo M, Topp SD, Smith BN, Nishimura AL, Chen H-J, Gkazi AS, et al. ALS-associated missense and nonsense TBK1 mutations can both cause loss of kinase function. Neurobiol Aging. 2018;71:266. e1-266.e10

87. Verheijen J, van der Zee J, Gijselinck I, Van den Bossche T, Dillen L, Heeman $B$, et al. Common and rare TBK1 variants in early-onset Alzheimer disease in a European cohort. Neurobiol Aging. 2018;62:245. e1-245.e7

88. Brouwers N, Sleegers K, Van Broeckhoven C. Molecular genetics of Alzheimer's disease: an update. Ann Med. 2008;40:562-83.

89. Jonsson T, Atwal JK, Steinberg S, Snaedal J, Jonsson PV, Bjornsson S, Stefansson H, Sulem P, Gudbjartsson D, Maloney J, Hoyte K, Gustafson A, Liu Y, Lu Y, Bhangale T, Graham RR, Huttenlocher J, Bjornsdottir G, Andreassen OA, Jönsson EG, Palotie A, Behrens TW, Magnusson OT, Kong A, Thorsteinsdottir U, Watts RJ, Stefansson K. A mutation in APP protects against Alzheimer's disease and age-related cognitive decline. Nature. 2012; 488(7409):96-9. https://doi.org/10.1038/nature11283.

90. Jayadev S, Leverenz JB, Steinbart E, Stahl J, Klunk W, Yu C-E, Bird TD. Alzheimer's disease phenotypes and genotypes associated with mutations in presenilin 2. Brain. 2010;133(4):1143-54. https://doi.org/10.1093/brain/awq033.

91. El Kadmiri N, Zaid N, Zaid Y, Tadevosyan A, Hachem A, Dubé M-P, et al. Novel presenilin mutations within Moroccan patients with early-onset Alzheimer's disease. Neuroscience. 2014;269:215-22. https://doi.org/10.1016/ j.neuroscience.2014.03.052

92. Xia D, Watanabe H, Wu B, Lee SH, Li Y, Tsvetkov E, et al. Presenilin-1 knockin mice reveal loss-of-function mechanism for familial Alzheimer's disease. Neuron. 2015:85:967-81.

93. Veugelen S, Saito T, Saido TC, Chávez-Gutiérrez L, De Strooper B. Familial Alzheimer's disease mutations in presenilin generate amyloidogenic $A \beta$ peptide seeds. Neuron. 2016;90:410-6.

94. Escamilla-Ayala A, Wouters R, Sannerud R, Annaert W. Contribution of the presenilins in the cell biology, structure and function of $\gamma$-secretase. Semin. Cell Dev. Biol; 2020.

95. Conidi ME, Bernardi L, Puccio G, Smirne N, Muraca MG, Curcio SAM, et al. Homozygous carriers of APP A713T mutation in an autosomal dominant Alzheimer disease family. Neurology. 2015;84:2266-73.

96. Canevelli M, Piscopo P, Talarico G, Vanacore N, Blasimme A, Crestini A, Tosto G, Troili F, Lenzi GL, Confaloni A, Bruno G. Familial Alzheimer's disease 
sustained by presenilin 2 mutations: systematic review of literature and genotype-phenotype correlation. Neurosci Biobehav Rev Pergamon. 2014; 42:170-9. https://doi.org/10.1016/j.neubiorev.2014.02.010.

97. Wijsman EM, Daw EW, Yu X, Steinbart EJ, Nochlin D, Bird TDB, et al. APOE and other loci affect age-at-onset in Alzheimer's disease families with PS2 mutation. Am J Med Genet - Neuropsychiatr Genet. 2005;132B(1):14-20. https://doi.org/10.1002/ajmg.b.30087.

98. Arboleda-Velasquez JF, Lopera F, O'Hare M, Delgado-Tirado S, Marino C, Chmielewska N, Saez-Torres KL, Amarnani D, Schultz AP, Sperling RA, Leyton-Cifuentes D, Chen K, Baena A, Aguillon D, Rios-Romenets S, Giraldo M, Guzmán-Vélez E, Norton DJ, Pardilla-Delgado E, Artola A, Sanchez JS, Acosta-Uribe J, Lalli M, Kosik KS, Huentelman MJ, Zetterberg H, Blennow K, Reiman RA, Luo J, Chen Y, Thiyyagura P, Su Y, Jun GR, Naymik M, Gai X, Bootwalla M, Ji J, Shen L, Miller JB, Kim LA, Tariot PN, Johnson KA, Reiman EM, Quiroz YT. Resistance to autosomal dominant Alzheimer's disease in an APOE3 Christchurch homozygote: a case report. Nat Med. 2019;25(11):16803. https://doi.org/10.1038/s41591-019-0611-3.

99. Pottier C, Zhou X, Perkerson RB, Baker M, Jenkins GD, Serie DJ, et al. Potential genetic modifiers of disease risk and age at onset in patients with frontotemporal lobar degeneration and GRN mutations: a genome-wide association study. Lancet Neurol. 2018;17:548-58.

100. Marder K, Wang Y, Alcalay RN, Mejia-Santana H, Tang MX, Lee A, et al. Agespecific penetrance of LRRK2 G2019S in the Michael J. Fox Ashkenazi Jewish LRRK2 Consortium Neurology Lippincott Williams and Wilkins; 2015;85:89-95.

101. Carmine Belin A, Westerlund M, Sydow O, Lundströmer K, Håkansson A, Nissbrandt H, Olson L, Galter D. Leucine-rich repeat kinase 2 (LRRK2) mutations in a Swedish Parkinson cohort and a healthy nonagenarian. Mov Disord. 2006;21(10):1731-4. https://doi.org/10.1002/mds.21016.

102. Brown E, Blauwendraat C, Trinh J, Rizig M, Nalls A, Leveille E, et al. Analysis of DNM3 and VAMP4 as genetic modifiers of LRRK2 Parkinson's disease. Neurobiol. Aging 2021;97:148.e17-148.e24. https://doi.org/10.1016/j. neurobiolaging.2020.07.002. Epub $2020 \mathrm{Jul} 13$.

103. Nguyen HP, Van Broeckhoven C, van der Zee J. ALS genes in the genomic era and their implications for FTD. Trends Genet; 2018;34(6):404-23. https:// doi.org/10.1016/j.tig.2018.03.001. Epub 2018 Mar 28.

104. Saunders AM, Strittmatter WJ, Schmechel D, George-Hyslop PH, Pericak-Vance MA, Joo SH, et al. Association of apolipoprotein E allele epsilon 4 with lateonset familial and sporadic Alzheimer's disease. Neurology. 1993;43:1467-72.

105. Farrer LA, Cupples LA, Haines JL, Hyman B, Kukull WA, Mayeux R, Myers RH, Pericak-Vance MA, Risch N, van Duijn C. Effects of age, sex, and ethnicity on the association between apolipoprotein E genotype and Alzheimer disease. JAMA. 1997;278(16):1349-56. https://doi.org/10.1001/jama.1997.03550160069041.

106. Pericak-Vance MA, Bebout JL, Gaskell PC, Yamaoka LH, Hung WY, Alberts MJ, et al. Linkage studies in familial Alzheimer disease: evidence for chromosome 19 linkage. Am J Hum Genet. 1991;48:1034-50.

107. Holstege H, van der Lee SJ, Hulsman M, Wong TH, van Rooij JG, Weiss M, et al. Characterization of pathogenic SORL1 genetic variants for association with Alzheimer's disease: a clinical interpretation strategy. Eur J Hum Genet. 2017;25(8):973-81. https://doi.org/10.1038/ejhg.2017.87.

108. Zhao L. CD33 in Alzheimer's disease - biology, pathogenesis, and therapeutics: a mini-review. Gerontology. 2019:323-31.

109. Cady J, Allred P, Bali T, Pestronk A, Goate A, Miller TM, Mitra RD, Ravits J, Harms MB, Baloh RH. Amyotrophic lateral sclerosis onset is influenced by the burden of rare variants in known amyotrophic lateral sclerosis genes. Ann Neurol. 2015;77(1):100-13. https://doi.org/10.1002/ana.24306.

110. Moreno F, Indakoetxea B, Barandiaran M, Caballero MC, Gorostidi A, Calafell $F$, et al. The unexpected co-occurrence of GRN and MAPT p.A152T in Basque families: clinical and pathological characteristics. Dermaut B, editor. PLoS One; 2017;12:e0178093.

111. Perrone F, Bjerke M, Hens E, Sieben A, Timmers M, De Roeck A, et al. Amyloid- $\beta 1-43$ cerebrospinal fluid levels and the interpretation of APP, PSEN1 and PSEN2 mutations. Alzheimers Res Ther. 2020;12:108.

112. Keogh MJ, Wei W, Aryaman J, Wilson I, Talbot K, Turner MR, McKenzie CA, Troakes C, Attems J, Smith C, al Sarraj S, Morris CM, Ansorge O, Pickering-Brown S, Jones N, Ironside JW, Chinnery PF. Oligogenic genetic variation of neurodegenerative disease genes in 980 postmortem human brains. J Neurol Neurosurg Psychiatry. 2018;89(8):813-6. https://doi.org/10.1136/jnnp-2017-317234.

113. De Roeck A, Van Broeckhoven C, Sleegers K. The role of ABCA7 in Alzheimer's disease: evidence from genomics, transcriptomics and methylomics. Acta Neuropathol; 2019;138(2):201-20. https://doi.org/10.1007/ s00401-019-01994-1. Epub 2019 Mar 22.
114. Cuyvers E, De Roeck A, Van Den Bossche T, Van Cauwenberghe C, Bettens K, Vermeulen S, et al. Mutations in ABCA7 in a Belgian cohort of Alzheimer's disease patients: a targeted resequencing study. Lancet Neurol. 2015;14:814-22.

115. May P, Pichler S, Hartl D, Bobbili DR, Mayhaus M, Spaniol C, et al. Rare ABCA7 variants in 2 German families with Alzheimer disease. Neurol Genet. 2018;4:e224.

116. Cacace R, Heeman B, Van Mossevelde S, De Roeck A, Hoogmartens J, De Rijk P, et al. Loss of DPP6 in neurodegenerative dementia: a genetic player in the dysfunction of neuronal excitability. Acta Neuropathol. 2019;137:901-18.

117. Ebbert MTW, Farrugia SL, Sens JP, Jansen-West K, Gendron TF, Prudencio M, et al. Long-read sequencing across the C9orf72 'GGGGCC' repeat expansion: implications for clinical use and genetic discovery efforts in human disease. Mol Neurodegener; 2018;13:46.

118. De Roeck A, Duchateau L, Van Dongen J, Cacace R, Bjerke M, Van den Bossche T, et al. An intronic VNTR affects splicing of ABCA7 and increases risk of Alzheimer's disease. Acta Neuropathol. 2018;135:827-37.

119. Del-Aguila JL, Li Z, Dube U, Mihindukulasuriya KA, Budde JP, Fernandez MV, et al. A single-nuclei RNA sequencing study of Mendelian and sporadic AD in the human brain. Alzheimer's Res Ther. 2019;11:71.

120. Li Z, Del-Aguila JL, Dube U, Budde J, Martinez R, Black K, et al. Genetic variants associated with Alzheimer's disease confer different cerebral cortex cell-type population structure. Genome Med. 2018;10:43.

121. Lundberg E, Borner GHH. Spatial proteomics: a powerful discovery tool for cell biology. Nat Rev Mol Cell Biol. 2019;20(5):285-302. https://doi.org/10.103 8/s41580-018-0094-y.

122. Gijselinck I, Van Mossevelde S, Van Der Zee J, Sieben A, Engelborghs S, De Bleecker J, et al. The C9orf72 repeat size correlates with onset age of disease, DNA methylation and transcriptional downregulation of the promoter; 2015. p. 1-13.

123. Toledo JB, Arnold M, Kastenmüller G, Chang R, Baillie RA, Han X, Thambisetty M, Tenenbaum JD, Suhre K, Thompson JW, John-Williams LS, MahmoudianDehkordi S, Rotroff DM, Jack JR, Motsinger-Reif A, Risacher SL, Blach C, Lucas JE, Massaro T, Louie G, Zhu H, Dallmann G, Klavins K, Koal T, Kim S, Nho K, Shen L, Casanova R, Varma S, Legido-Quigley C, Moseley MA, Zhu K, Henrion MYR, van der Lee S, Harms AC, Demirkan A, Hankemeier T, van Duijn C, Trojanowski JQ, Shaw LM, Saykin AJ, Weiner MW, Doraiswamy PM, Kaddurah-Daouk R, Alzheimer's Disease Neuroimaging Initiative and the Alzheimer Disease Metabolomics Consortium. Metabolic network failures in Alzheimer's disease: a biochemical road map. Alzheimers Dement. 2017; 13(9):965-84. https://doi.org/10.1016/j.jalz.2017.01.020.

124. Sommen M, Wuyts W, Van Camp G. Molecular diagnostics for hereditary hearing loss in children. Expert Rev Mol Diagn. 2017;17(8):751-60. https:// doi.org/10.1080/14737159.2017.1340834.

\section{Publisher's Note}

Springer Nature remains neutral with regard to jurisdictional claims in published maps and institutional affiliations. 